

\title{
Further Observations on Endemic Telmatobiid Frogs From the Patagonian Somuncurá Plateau (Río Negro, Argentina)
}

\author{
J. M. Cei \\ Instituto Biologia Animal \\ Universidad Nacional de Cuyo \\ Mendoza, Argentina
}

ABSTRACT - Males and tadpoles of Telmatobius somuncurensis, living in thermal springs $\left(20^{\circ}\right.$. $22^{\circ} \mathrm{C}$ ) are described. Preliminary observations on the spermatogenic cycle of the species are discussed. Ecological observations on the Somuncura plateau, 700-800 m, are reported.

\section{INTRODUCTION}

The geological history and ecological peculiarities of the Somuncura Plateau in the Argentine Patagonian province of Río Negro $\left(40^{\circ} 50^{\prime}\right.$ and $41^{\circ} 45^{\prime}$ South Lat.; $66^{\circ}$ and $68^{\circ}$ West Long.) have been discussed (Cei, 1969). Between December, 1967, and April, 1968, I studied the spring, summer and fall biological activities of the biocenotic communities there. The endemic Telmatobiini are located both in the crater hollows and clay lagoons of the open stepparian uplands, $1400 \mathrm{~m}$ (Te/matobius reverberii), and in the rocky streams of the narrow valleys, such as El Rincón Spring, $700 \mathrm{~m}$ (Telmatobius somuncurensis). Adult types of both sexes of Telmatobius reverberii and its larval stages and biology have been reported (Cei, 1969). However, Telmatobius somuncurensis was described only from adult females; larval stages and adult males have not been described. Field work in the Somuncurá plateau (November, 1968 and May, 1969) gave me opportunities for additional studies on the later form and its environment. Thus male specimens and tadpoles of Telmatobius somuncurensis are here described, together with some ecological features of this very localized Telmatobiid frog.

Description of Males of Telmatobius somuncurensis:-Seven specimens are available: IBMUNC 2004/1-3, EI Rincón Stream 55 km SSW Valcheta, Río Negro, Argentine, on the basaltic slopes of Somuncurá plateau $(700 \mathrm{~m})$, collected 19 November, 1968, by the author (Fig. 1A); IBM-UNC 2040/1-3, same data except 10 May, 1969; IBM-UNC 2041/8, Ariete Spring, 4 km SW EI Rincón Spring, Somuncurá plateau $(800 \mathrm{~m}) 10$ May, 1969, same collector. The "typi-


head length/snout-vent length 34.8 per cent; head width $10.5 \mathrm{~mm}$; head width/snout-vent length 33.3 per cent; femur $15 \mathrm{~mm}$; tibia length $14.5 \mathrm{~mm}$; tibia length/snout-vent length 46.0 per cent; foot length (from inner metatarsal tubercle to tip of largest toe) $19 \mathrm{~mm}$; arm (from axilla to tip of largest finger) $20.1 \mathrm{~mm}$; diameter of eye $4 \mathrm{~mm}$. Snout gently rounded as in females; nose not protruding; canthus scarcely evident; loreal region somewhat flat; top of the head gently declivous; lips rounded; internarial distance $3 \mathrm{~mm}$; interorbital distance $2.5 \mathrm{~mm}$, equal to width of eyelid $(2.5 \mathrm{~mm}$.) A faint supratympanic dermal fold from posterior corner of eye to insertion of forelimb; tympanum small, scarcely evident, diameter $1.8 \mathrm{~mm}$; forearm stronger than in females, with some low tubercules on its ventrolateral surface; small pigmented thumb pads as secondary sex-characteristics on dorsal surface of first finger; second finger shorter than the fourth; fingers free, without cutaneous borders; subarticular tubercles conical, low; metacarpal tubercles reduced, the outer almost indistinguishable. Heels not overlapping when hind limbs adpressed; tibiotarsal articulation reaching eye; no tarsal fold; inner metatarsal tubercules reduced; subarticular tubercles small, conical, not prominent; length of digits from shortest to longest 1-2-5-3-4; toes about one-third webbed, with broad cutaneous borders to tip. Symmetrical rounded pigmented structures on center of upper and lower border of iris. Cloacal appendix 



FIGURE 1. Telmatobius somuncurensis, males. A, adult, slightly enlarged; B, C, everted cloaca, strongly enlarged. present (Fig. 1, B-C). Skin smooth, with very reduced dorsal warts; tongue subcircular, free posteriorly; premaxillary-maxillary teeth strong; vomerine teeth reduced, in two slightly prominent patches between and on median line of choanae. Pectoral girdle as in female.

Color (in alcohol):-Brownish on dorsal surface of head, body and legs; irregular dorsal dark spots, somewhat reticulated on the sides and upper surface of thigh, tibiae and tarsi; belly yellowish or creamish, with evident reticulated dark spots. Color (in life): Bright brown-yellowish above, with small dark spots and trace of a light yellowish medial stripe on anterior part of dorsum; belly yellowish with dark reticulated spots; iris golden, with black upper and lower protruding structures (menisci).

In the other six male adult specimens, snout-vent lengths between $28.35 \mathrm{~mm}$ (mean $30.8 \mathrm{~mm}$ ); head-length/snout-vent ratio 31.8 37.0 per cent (mean 34.9); head-width/snoutvent ratio 31.2-33.9 percent (mean 32.6); tibia-length/snout-vent ratio $42.8-48.3$ percent (mean 46.8); variation in color pattern slight.

Many additional female specimens have been found both in EI Rincón Spring 14 specimens, November, 1968; 4 specimens, May, 1969) and in Ariete Spring (7 specimens, May, 1969).

Male specimens are smaller than females.

Tadpoles of Telmatobius somuncurensis:-The larvae available are as follows: IBM-UNC 2005, 12 larvae, EI Rincon Spring, Somuncura, 700 meters, 18 November, 1968; IBM-UNC 2005, 3 metamorphosing larvae, from same locality, 18 November, 1968. All collected by the author.

Diagnosis:-A middle-sized Telmatobiid-like tadpole, body slender, somewhat bulky, caudal muscle well developed; fin high and thin, tip of tail enlarged, eyes and nostrils prominent and dorsal; spiracle sinistral, anus ventral. Suctorial mouth and lips moderately folded; very dark brown pigmentation, belly unpigmented; maximum observed total length $44 \mathrm{~mm}$.

Description:-Tadpoles belonging to our series 2005 may be divided in three groups. One specimen having a total length of $25 \mathrm{~mm}$ does not show traces of buds or small hind limbs, but buds are present in a group of 7 tadpoles of $32-36 \mathrm{~mm}$, and small hind limbs are evident in a third group of 4 tadpoles, $40-44 \mathrm{~mm}$. In one specimen having a total length of $42 \mathrm{~mm}$ the body length is $16 \mathrm{~mm}$, body thickness $7 \mathrm{~mm}$, width of fin $10 \mathrm{~mm}$. The following description is based primarily on specimens having a total length of 36 and $40 \mathrm{~mm}$. (Fig. 2a, c, d)

Body and head almost twice as wide; head wider than body; body slender, somewhat bulky; ventral profile not convex; snout sucker-like, slightly protruding; eyes large, dorsal; upper and lower menisci present in iris; interocular distance less than distance of eyes from tip of snout, narrower than width of anterior dorsal musculature; nostrils evident, pigmented, dorsal, salient; distance between nostrils less than their distance from eye; distance of nostril from snout equal to their distance from eye; internasal distance $2 / 3$ interorbital distance; spiracle sinistral, opening ventrolaterally, slightly nearer ventral base of tail than tip of snout; spiracular tube about equal to diameter of eye; anal tube ventral, on ventral fin. Tail musculature longer than head and body; dorsal and ventral fin well developed, lowest near body, becoming higher posteriorly, as musculature narrows; tip of tail enlarged; dorsal and ventral fins ending at base of 




$\times 2$



B

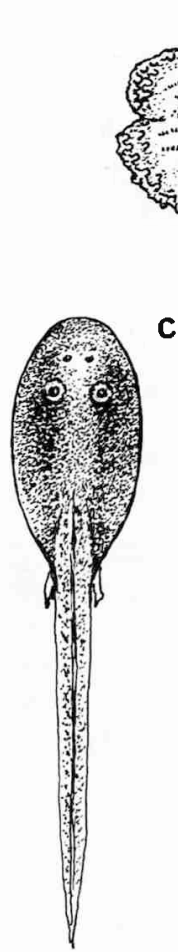

c



FIGURE 2. Tadpole of Telmatobius somuncurensis. A, lateral view; B, mouth enlarged; C, D, dorsal and lateral view. tail. Skin pigmented, viscera almost visible ventrally; orbital distance $2 / 3$ width of mouth; lips thickened, protruding, slightly folded laterally, edges bordered by numerous, marginal papillae. Mouthparts leptodactylid; tooth rows 2/3; upper rows about equal in length, slightly longer than upper beak; second upper row and first lower row narrowly interrupted; other rows continuous, slightly shorter than second row. Horny black beak well developed, sharply serrated (Fig. 2b).

Color (in life):-Brownish-gold dorsally; abdomen reddish-gray, scarcely-pigmented; internal organs scarcely visible; dorsum mottled with abundant melanophores and guanophores: caudal musculature brownish, mottled by melanic blotches. Caudal fin transparent, mottled by brownish spots.

Color (in formalin):-Brownish; chromatophores metamerically disposed on dorsal caudal musculature. Belly and fin transparent.

Tadpole biology:-Free-swimming and very fast, non-gregarious tadpoles, living on the bottom of the stream and in its shallow pools. Omnivourous and slime-eating habits in accordance with the protruding mouth and snout. On 15-20 November 1968, larvae at all stages of development were found in the El Rincón Stream. Metamorphosing individuals were observed on 30 November 1968. Size of froglets was $18 \mathrm{~mm}$ snout-vent. Metamorphosing tadpoles with developed forelimbs may attain a total length of $46-49 \mathrm{~mm}$.

\section{GENERAL REMARKS AND ECOLOGICAL OBSERVATIONS}

The northern basaltic slopes of the Meseta of Somuncura are surrounded by a wreath

of thermal springs, following levels between 800 and $500 \mathrm{~m}$. Many of these rocky-filtered waters, of low salinity (486 mg/liter), flow into the so-called Valcheta stream and thence northward to the deep salt basin of the Tres Picos dry lagoons. Water temperature of the springs is constant in every season at $20^{\circ}-22^{\circ} \mathrm{C}$, even in the cold winter months, probably as a terminal phase of the ancient volcanic activity in the Somuncurá region.

Current thermal waters, such as El Rincón Spring or the nearby Ariete Spring, are the ecological niche of Telmatobius somuncurensis. The small endemic gymnocharacid fish (Gymnocharacinus bergi) lives in the same specialized environment, swimming very speedily in the mosscrowded rocky pools, with the tadpoles of Telmatobius somuncurensis and Bufo arenarum. $B$. arenarum reaches its upper distributional limit there; Odontophrynus occidentalis and the Patagonian frog Pleurodema bufonina may also be present.

Larval stages of Telmatobius somuncurensis have been observed only in late November. No tadpoles were found in April and May in such an ecologically homeostatic environment as the thermal springs of EI Rincón. It may be assumed that breeding and egg-laying of Telmatobius somuncurensis occurs in October or early November. In contrast larvae of Telmatobius reverberii 




FIGURE 3. A. Testis of Telmatobius somuncurensis (x280), 10 December 1968); B, C, same (x750), (13 May 1969); D. Testis of Pleurodema bufonina, (x280), Laguna Blanca, Neuquen, Argentina, $1300 \mathrm{~m}$ (28 February 1963); E. Testis of Telmatobius hauthali (x750), Infiernillo, Tafi del Valle, Tucuman, Argentina, $1300 \mathrm{~m}$ (6 May 1969); F. same, Telmatobius halli (x650), San Pedro, Atacama, Chile, $2500 \mathrm{~m}$ (28 May 1966). 
were found in December and April in the temporary clay lagoons of the Somuncura uplands (Cei, 1969). Late mating activity may occur in this species, in accordance with the very irregular rainfall in the uplands. During my last visit to the Somuncura plateau in May, 1969, all the

clay lagoons reported in my previous papers were dry.

Histological studies of the gonads of adult male Telmatobius somuncurensis revealed enormous masses of sperm in the dilated tubules of November samples, but only a reduced number of spermatogonia and new spermatocytes was present (Fig. 3a). Testes of May samples also reveal a great quantity of ripe sperms regularly grafted in the Sertoli cells; spermatogenetic activity is still remarkably prominent, (Fig. $3 b, c)$.

Such a functional condition of the annual spermatogenetic wave is in accordance with the tremendous size attained at that time by the testes. The snout-vent length/testes-length ratios of five male specimens range between 2.28 and 2.91 (mean 2.61). Analogous ratios are not evident in any other Telmatobiid frogs but are shown by another Patagonian anuran, Pleurodema bufonina, in which a spermatogenic block and storage of ripe sperms occurs in the testes between March and October (Fig. 3d). The male gonadal rhythms of Pleurodema bufonina seem to belong to the self-determined or autonomous endocrinous pattern, almost independent of any direct influence of the external factors (Cei, 1961, 1962; Van Oordt, 1960). The periodic regulation of the gonadal cycle of Telmatobius somuncurensis does not belong to such a category, probably because of thespecialized environmental conditions of the Somuncura form, living in thermal springs of constant temperature. Such response is in accordance with the most favorable thresholds for hypophyseal and gonadal activities. It might be mentioned that continuous annual spermatogenetic cycle is shown by other species of Telmatobius I have observed, such as $T$. hauthali, T. halli, and $T$. reverberii from the same area (Fig. $3 e, f$ ).

This project has been supported by grant No. 2158/a of the Consejo Nacional de Investigaciones Cientificas y Tecnicas, Buenos Aires.

\section{LITERATURE CITED}

Cei. J. M. 1961. Bipolaridad del ciclo espermatogenetico discontinuo autoregulado en los Anfibios. Rev. Arg. Biol. 37: 48-51.

1962 Pleurodema bufonina Bell, anfibio australe con ciclo spermatogenetico discontinuo autoregolato. Arch. Zool. Ital. 46: 167-180.

1969. The Patagonian Telmatobiid fauna of the volcanic Somuncura Plateau (Rio Negro, Argentina). J. of Herp. 3(1-2): 1-18.

Van Oordt, P. G. W. J. 1960. The influence of internal and external factors in the regulation of the spermatogenetic cycle in Amphibia. Symp. Zool. Soc. Lond. 2: 29-52. 